\title{
A TERÜLETFEJLESZTÉS MENEDZSMENTJE DIRECTION DE L'ARCHITECTURE ET DE L'URBANISME: TERRITOIRE A CONSTRUIRE - OBSERVER ET AGIR POUR LE DÉVELOPPEMENT LOCAL
}

(Les Editions Villes et territoire, Arche de la Défense, Paris 1994)

\section{FẢTH JÁNOS}

A könyv címe és alcíme jól kifejezik a könyv mondanivalóját, ám előbbi nehezen lefordítható, mert a gondolat meglehetősen provokatív. A cím szerint a tér nem adott, azt meg kell alkotni, szerkeszteni, komponálni. Ez azt jelenti, hogy a "projekt" éppen úgy meghatározhatja a "térséget", mint ahogyan maga a tér is meghatározó eleme a "projekt"-nek. Az alcím a megfigyelést és a cselekvést, az akciót, illetve a kettő szoros kapcsolódását emelik ki. A szerzők szerint megfigyelés, az adott térségröl történö információ-szerzés elsődleges fontosságú.

A könyv egyik súlypontja a cselekvés, amely a szereplők, a közösségek, a közhivatalok, a kutatók, a tervezők, a fejlesztők, a vállalatok és kủlönböző érdekcsoportok együttmüködésére épül. Ily módon alapvető jelentőségủvé válik az az összetett tevékenység, amelyet röviden menedzsmentnek nevezünk. A könyv nem monográfia, és nem statisztikai elemzésekre épül. Célja, hogy az olvasót gondolkodásra, informálódásra ösztönözze, hiszen minden térség esetében figyelembe kell venni a sajátos vonásokat, nincsenek másolható "receptek". A szerzők szerint a cselekvéshez szükség van a "fejlódés pedagógiájára": tájékozódni, tájékoztatni, szervezni és meggyözni kell a siker érdekében.

A könyv első fejezete a területfejlesztés problematikáját, a helyi fejlödés dinamikáját, vizsgálatának módszertanát, a cselekvés elsődlegességét tárgyalja. A második részben a kulcsfontosságúnak tartott tényezöket: a programozást, az információ-áramlást, továbbá a közintézmények és -szervezetek szerepét, felelösségét elemzik a szerzök. A könyv harmadik részében az információk értékelése, annak alapelvei, a konkrét helyzetekhez történó alkalmazkodás és a fejlesztés pedagógiája állnak a középpontban. A negyedik fejezet pedig - mintegy 39 oldalnyi terjedelemben - két esettanulmányon keresztül mutatja be a lefektetett elvek és leírt módszerek alkalmazhatóságát. A könyv utolsó, nagyobb egysége hét fejlesztési problémakört ölel fel és - ugyancsak a három elmélet és módszertani fejezetre alapozva - kilenc konkrét projektet mutat be egységes felépitésben és megközelítésben. 
A könyvet nagy számú táblázat, diagram teszi szemléletessé. A hivatkozott forrásokon keresztül pedig bepillantást nyerhetünk a francia terület- és városfejlesztési, illetve regionális tervezési szakirodalomba is.

A könyv megírásában résztvevő nagy számú - mintegy húsz - szakember, három, szakmailag elismert intézmény koordinációjának köszönhetöen egységes, logikus felépítésủ müvet alkotott. A könyv a Service Technique de l'Urbanisme (STU) és a Villes et Territoires (Centre d'Études et de Perspective) gondozásában jelent meg. A munka gyakorlatias beállítottságára utal, hogy a címlapon szereplö Direction de l' Architecture et de l'Urbanisme (Építésügyi és Városépítési Igazgatóság - szerk.) a Ministere de l'Équipement des Transports et du Tourisme (Közlekedési és Idegenforgalmi Minisztérium) része.

A könyv igényes elméleti fejezetei és gyakorlati példái miatt alkalmas a területfejlesztés menedzsmentjének szemináriumi feldolgozására, illetve a területfejlesztés szereplöinek mobilizálására. A mü alkalmat adhat arra is, hogy a francia területfejlesztés elméleti és gyakorlati szakértöivel közös programokat szervezzünk (konferenciák, közös tervezési programok, intézetek közötti tapasztalat- és szakember-csere).

A munka feltétlenül érdemes arra, hogy több nyelvre - köztuk magyarra - is lefordítsák. Számolni kell azonban azzal, hogy a megközelítés eredetisége miatt a fordítás speciális nyelvi ismereteket igényel, szilikségessé válhat a magyar nyelvben eddig nem használt, új szakszavak megalkotása, kidolgozása is. 